\title{
Availability of Micronutrient Cations in Soils as Influenced by Phosphorus Fertilization- A Review
}

\author{
Harpreet Kaur* \\ Department of Soil Science, College of Agriculture, Punjab Agricultural University, India \\ *Corresponding author
}

\section{Keywords \\ root development, cell division, flowering seed and fruit formation \\ Article Info \\ Accepted: \\ 20 August 2019 \\ Available Online: \\ 10 September 2019}

\section{A B S T R A C T}

Phosphorus and micronutrients (zinc, copper, iron and manganese) are the essential nutrients which are required for normal plant growth. Phosphorus and all micronutrient cations are mutually antagonistic in certain circumstances which can cause yield reductions in many crops due to their deficiencies. Deficiencies typically happen when a nutrient is available in small amounts. In this phenomenon, the nutrient is present in marginal to normal levels but the antagonizing nutrient is available in such a large amount that it induces the deficiency of the other. The effect of phosphorus application on the availability of micronutrients showed that the application of phosphorus decreases the concentrations of $\mathrm{Fe}, \mathrm{Zn}, \mathrm{Cu}$ and $\mathrm{Mn}$ in the soils which indicate negative interactions between $\mathrm{P}$ and micronutrient cations while the concentration of $\mathrm{Mn}$ increases in some cases indicating synergistic as well antagonistic effect of $\mathrm{P}$ application on Mn availability in soils to plants.

\section{Introduction}

Phosphorus has been considered to be the kingpin in agriculture because it plays a pivotal role in increasing crop production and improving the quality of crops. It is the second major essential element and is required by plants for root development, cell division, flowering seed and fruit formation (Brady, 1984). Phosphorus in soils occurs in the form of primary and secondary orthophosphate. Most possibly all crops take up $\mathrm{H}_{2} \mathrm{PO}_{4}{ }^{-}$more readily than $\mathrm{HPO}_{4}^{--}$and above $\mathrm{pH} 7.0$ the relative concentration of the divalent ion is greater than that of monovalent ion. India is the world's third largest producer of phosphatic fertilizers and second largest consumer after China (Prasad, 2012). If large amounts of $\mathrm{P}$ are supplied in soils, its luxury uptake may disturb the ratios of $\mathrm{P}$ to other nutrients including micronutrients (Tagliavini et al., 1991). The present day modern agriculture aims at achieving maximum production per unit area per unit time per unit cost. This has created an imbalance of nutrients in soils and crops not only with 
respect to macronutrients but also the micronutrients. Rice-wheat is the major cropping system of Punjab and normally phosphorus is applied to wheat. However, in some areas farmers are applying phosphorus to both the crops. But only one- third of applied $\mathrm{P}$ is taken up by the current crop that may lead to the buildup of $\mathrm{P}$ in plough layer of soils over a period of time. At present only $36 \%$ of the area in Punjab is low in $\mathrm{P}$ supplying capacity (Sharma et al., 2011). Build up of $\mathrm{P}$ in soils can affect $\mathrm{pH}, \mathrm{CEC}$ and surface charge of soils which in turn may alter the equilibria of micronutrients among their various chemical pools. Not only this, build up of $\mathrm{P}$ in soils may lead to various types of nutrient interactions in soils and plants. Nutrient interactions in crop plants are probably one of the most important factors affecting the yields of annual crops. An interaction takes place when the supply of one of the nutrients affects the absorption, distribution or function of the other and it may be negative, positive or neutral (Fageria, 2001). Thus, depending upon the nutrient supply, the interactions between nutrients can either induce deficiencies or toxicities and can modify the growth response. The plants require essential nutrients viz., primary, secondary and micro nutrients. One of the fertilizers that are used a lot in various crop plants is phosphorus, which is applied as phosphorus fertilizers to the soil. The deficiency of micronutrients may emerge when the supply of micronutrients to the soil is less compared to removal through crop harvest which in turn limits crop productivity (Shukla et al., 2009). If large amounts of $\mathrm{P}$ are supplied in soils, its luxury uptake may disturb the ratios of $\mathrm{P}$ to other nutrients including micronutrients (Tagliavini et al., 1991). Thus, an understanding of the interaction of phosphorus with other nutrients can be of help to maintain a balanced supply of nutrients to get the optimum crop yields.

\section{Effect of phosphorus fertilization on zinc in soil}

Zinc is an important essential element present in plant enzymatic systems. Among the interactions involving macro and micronutrients the interaction between phosphorus and zinc is of greatest potential significance. This interaction is often negative (antagonistic) especially when a soil is deficient in both the nutrients but only one of them is applied through fertilizers. Das et al., (2005) in a greenhouse experiment at the Indian Institute of Horticultural Research (IIHR), Bangalore reported the decrease in the amount of $\mathrm{Zn}$ due to combined application of $\mathrm{P}$ and $\mathrm{Zn}$ might be explained as the antagonistic effect between them. It has been reported that the interaction between $\mathrm{Zn}$ and $\mathrm{P}$ occurred in soil because added $P$ decreased the available $\mathrm{Zn}$ content in plants. The amount of $\mathrm{P}$ and $\mathrm{Zn}$ in soils showed an increase with their separate applications either as soil or foliar spray while that of the same value significantly decreased both in soils and plants due to their combined applications, suggesting a mutual antagonistic effect between $\mathrm{Zn}$ and $\mathrm{P}$ affecting each other's availability in soil and content in the stevia plant. Meena et al., (2019) observed that Zinc availability decreases with application of each successive phosphorus level but it was increased with application of zinc. High levels of available phosphorus in soil or high dose of phosphorus application may induce zinc deficiency in the soil characterized by low concentration of available zinc. In an incubation study, Mandal and Haldar, (1980) observed that application of phosphorus@5 and $10 \mathrm{mg} \mathrm{kg}$-1 soil in lowland rice soils of West Bengal significantly decreased the contents of DTPA-extractable $\mathrm{Zn}, \mathrm{Cu}, \mathrm{Fe}$ and $\mathrm{Mn}$. The rate of decrease gradually reduced with increasing period of incubation from 10 to 70 days. They further observed that the depressive effect of $\mathrm{P}$ on 
extractable $\mathrm{Zn}$ was more pronounced on native rather than applied $\mathrm{Zn}$. Manchanda et al., (2012) observed a steep fall in DTPA- Zn when P: Mn ratio in soil was 6.0 and reported that a P: Mn ratio of 3.28 in soil produced $80 \%$ of the maximum dry matter yield of shoot of wheat. Furthermore, P-Zn relationship in soils and plants may also be governed by factors like organic matter (Nayak and Gupta, 2000), plant parts (Reddy and Yadav, 1994), plant species and growth stages (Islam et al., 2005). Dwivedi et al., (1975) observed P induced $\mathrm{Zn}$ deficiency in corn when P was applied @ $120 \mathrm{mg} \mathrm{kg}^{-1}$ soil in a $\mathrm{Zn}$ deficient soil (DTPA- Zn $0.2 \mathrm{mg} \mathrm{kg}^{-}$ ${ }^{1}$ soil). They further observed that high levels of $\mathrm{P}$ rendered the applied $\mathrm{n}$ unavailable to plants by immobilizing almost $40 \%$ or more of the total $\mathrm{Zn}$ absorbed in roots and 20 per cent or more at the nodes of the stem. In a nutrient culture experiment, Soltangheisi et al., (2013) observed that $\mathrm{Zn}$ deficiency in sweet corn can enhance $\mathrm{P}$ uptake and translocation to such an extent that $\mathrm{P}$ may accumulate to toxic levels in its leaves. Mishra and Abidi, (2010) reported that $\mathrm{P}$ and $\mathrm{Zn}$ application had a synergistic impact on the 1000-seed weight and protein content of the wheat varieties.

\section{Effect of phosphorus fertilization on copper in soil}

Awan and Abbasi, (2000) observed that phosphorus application increased $\mathrm{P}$ concentration while decreased the copper concentration in the maize plants in sandy loam soil, leading to conclude that an interaction between $\mathrm{P}$ and $\mathrm{Cu}$ in soil occurs which effect the production of maize fodder significantly. Mandal and Haldar, (1980) reported that the decrease in uptake of $\mathrm{Zn}, \mathrm{Cu}$ and $\mathrm{Fe}$ by rice because of $\mathrm{P}$ application was due to decrease in the availability of these nutrients in soils. In a greenhouse study, Haldar and Mandal, (1981) observed that application of phosphorus in alluvial rice soils significantly increased the dry matter yield of root, shoot and grain. But it decreased the concentration of $\mathrm{Zn}, \mathrm{Cu}, \mathrm{Fe}$ and $\mathrm{Mn}$ in both roots and shoots. This decrease in the concentration of elements in shoots was not due to the dilution effect or to the reduced rate of translocation from roots to tops. They observed that this decrease was more due to the changes in their availability in soil due to $\mathrm{P}$ application. Application of $100 \mathrm{~kg} \mathrm{P} \mathrm{ha}{ }^{-1}$ significantly decreased the $\mathrm{Cu}$ concentration in maize plants (Awan and Abassi, 2000). Similarly, an antagonistic effect of $\mathrm{P}$ on $\mathrm{Cu}$ concentration of wheat (Shukla and Singh, 1979; Javadi et al., 1991) has been observed.

\section{Effect of phosphorus fertilization on manganese in soil}

A synergistic (Kuo and Mikkelsen, 1981) as well antagonistic (Soni et al., 2000) effect of $\mathrm{P}$ fertilization on $\mathrm{Mn}$ availability in soils to plants has been reported. Singh et al., (2005) observed that availability of $\mathrm{Mn}$ in a near neutral non-calcareous soil was increased when the build up of available $\mathrm{P}$ in soil exceeded $60 \mathrm{mg} \mathrm{P} \mathrm{kg}{ }^{-1}$ soil. Chatterjee et al., (1983) reported a significant decrease in DTPA extractable Mn with P application @ $100 \mathrm{mg} \mathrm{P} \mathrm{kg}^{-1}$ in an acidic soil ( $\mathrm{pH}$ 6.5) incubated for 30 days. However, in an alkaline soil ( $\mathrm{pH}=7.6)$, Mamo and Parson, (1987) reported a significant increase in DTPA extractable Mn with P application @ 400 mg $\mathrm{P} \mathrm{kg}^{-1}$ soil incubated for 28 days. Misra and Mishra, (1968) reported that $\mathrm{P}$ application to alkali soils decreased the retention of Mn by soil colloids and increased the availability of $\mathrm{Mn}$. However, in near neutral soil $(\mathrm{pH}=7.3)$ having 11.5 ppm DTPA-Mn, the availability of $\mathrm{Mn}$ in soil was not influenced by $\mathrm{P}$ application even up to $120 \mathrm{~kg} \mathrm{P}_{2} \mathrm{O}_{5} \mathrm{ha}^{-1}$ (Rao et al., 1984). Singh et al., (2005) observed a significant increase in dry matter yield of root and shoot of wheat with graded levels of applied $\mathrm{P}$ in a Typic Haplustept but $\mathrm{P}$ and $\mathrm{Mn}$ 
concentration in both root and shoot were inversely related with each other. Soni et al., (2000) reported that when $\mathrm{P}$ and $\mathrm{Mn}$ was applied @ 0 to $60 \mathrm{mg} \mathrm{P} \mathrm{kg}^{-1}$ soil and 0 to 50 $\mathrm{mg} \mathrm{Mn} \mathrm{kg}{ }^{-1}$ soil respectively in a reclaimed sodic soil $(\mathrm{pH}=8.7)$ then increasing levels of $\mathrm{P}$ decreased the concentration of $\mathrm{Mn}$ in wheat at each level of applied Mn. Recovery of added $\mathrm{Mn}$ was lower at higher levels of $\mathrm{P}$ application. However, Karelia, (1990) and Patel, (1992) observed that application of $\mathrm{P}$ significantly increased the content and uptake of Mn by wheat crop.

\section{Effect of phosphorus fertilization on iron in soil}

An antagonistic effect of $\mathrm{P}$ on $\mathrm{Fe}$ concentration in moong bean has been observed (Yadav et al., 2002). Dhaliwal and Mandal, (2019) reported that the mean available $\mathrm{Fe}$ in soil at harvest extracted by DTPA decreased significantly by $3.2 \%, 4.5 \%$, and $6.9 \%$, respectively, over control with application of 100, 200 and $400 \mathrm{mg} \mathrm{P} \mathrm{kg-1}$ soil. So DTPA-Fe was significantly negatively correlated with Olsen $\mathrm{P}\left(\mathrm{r}=-0.833^{* *}\right)$. The decrease in availability of $\mathrm{Fe}$ with $\mathrm{P}$ fertilization may be due to the formation of $\mathrm{Fe}-$ phosphates in soil (Olsen, 1972). Intensive cultivation of high-yielding cultivars with heavy applications of nitrogen (N), phosphorus $(\mathrm{P})$, and potassium $(\mathrm{K})$ fertilizers leads to the occurrence of $\mathrm{Fe}$ and $\mathrm{Mn}$ deficiencies (Cakmak, 2002). Khan and Zande, (1976) and Badhe and Mundwaik, (1982) reported a significant decrease in Fe content of wheat plant with increasing dose of $P$ fertilizer. Karelia, (1990) found that application of $\mathrm{P}$ at its highest levels (P 180) significantly decreased the Fe content in grain and straw of wheat crop, whereas Fe uptake by grain and straw as well as its total uptake were significantly higher at P 120 level. Patel, (1992) observed that $\mathrm{Fe}$ content in grain was found to increase up to $60 \mathrm{~kg} \mathrm{P}_{2} \mathrm{O}_{5} \mathrm{ha}^{-1}$ of $\mathrm{P}$ application level but further addition of $\mathrm{P}$ (90 $\mathrm{kg} \mathrm{P}_{2} \mathrm{O}_{5} \mathrm{ha}^{-1}$ ) showed negative effect on $\mathrm{Fe}$ content.

Adriano et al., (1971) reported that in corn seedlings with high $\mathrm{P}$ levels, shoot growth was increased only by high $\mathrm{Zn}$. The most marked interaction at high $\mathrm{P}$ levels was between $\mathrm{Fe}$ and $\mathrm{Zn}$ which mutually antagonized translocation more than absorption. Dev et al., (1983) reported that application of $7.5 \mathrm{mg} \mathrm{P}$ $\mathrm{kg}^{-1}$ soil $\mathrm{P}$ enhanced the $\mathrm{Mn}$ concentration of chickpea while its concentration decreased when P was applied @ 15 and $30 \mathrm{mg} \mathrm{kg}^{-1}$ soil. In a field experiment Zhang et al., (2012) observed that application of phosphorus up to $400 \mathrm{~kg} \mathrm{P} \mathrm{ha}{ }^{-1}$ did not influence the DTPAextractable zinc, copper, iron and manganese in a alkaline calcareous loam soil under the wheat crop. However, they observed a significant reduction in the concentration of zinc in wheat grain by 17 to 56 per cent by $\mathrm{P}$ application. But the accumulation of shoot iron, copper and manganese was increased with applied P. Li et al., (2007) also did not observed any significant effect of $P$ application on DTPA extractable micronutrient cations in soil under long term inorganic and organic fertilizer application. Goel and Duhan, (2014) observed a significant decrease in DTPA extractable $\mathrm{Zn}, \mathrm{Cu}, \mathrm{Fe}$ and $\mathrm{Mn}$ with application of varying levels of $\mathrm{P}(0-$ $37.5 \mathrm{~kg} \mathrm{P} \mathrm{ha}{ }^{-1}$ ) to a Typic Torripsamment of Hisar. In an alkaline calcareous soil of Pakistan, Ali et al., (2014) observed a decrease in the availability of $\mathrm{Zn}$ and $\mathrm{Cu}$ but an increase in the availability of $\mathrm{Fe}$ and $\mathrm{Mn}$ with that application of $\mathrm{P}\left(0-150 \mathrm{~kg} \mathrm{Pha}^{-1}\right)$.

\section{References}

Adriano. D. C., Paulsen, G. M and Murphy, L. S. 1971. Phosphorus-iron and phosphorus-zinc relationships in corn (Zea mays L.) seedlings as affected by mineral nutrition. Agron J 63:36-39. 
Ali, F., Sadiq, A., Ali, I., Amin, M. and Amir, M. 2014. Effect of applied $\mathrm{P}$ on the availability of micronutrients in alkaline-calcareous soil. J Environ and Earth Sci 4:2224-3216.

Awan, Z. I. and Abbasi, M. K. 2000. Interactive effect of phosphorus and copper on maize growth. Pakistan J Agric Res 16:105-108.

Badhe, N. N. and Mundwaik, S. P. 1982. Effect of phosphorus concentration on $\mathrm{Fe}, \mathrm{Zn}, \mathrm{Cu}$ and $\mathrm{Mn}$ utilization by sorghum and wheat. Journal of Maharashtra Agricultural Universities 7 (2):148-150.

Brady, N.C. 1984. The nature and properties of soils, (9th Edition) Macmillan Publishing inc., New York, USA.

Cakmak, I. 2002. Plant nutrition research: Priorities to meet human needs for food in sustainable ways. Plant and Soil 247:3-24. doi:10.1023/A: 1021194511492.

Chatterjee, A. K., Mandal, L. N. and Haldar, M. 1983. Effect of phosphorus and zinc application on the extractable $\mathrm{Zn}$, $\mathrm{Cu}, \mathrm{Fe}, \mathrm{Mn}$ and $\mathrm{P}$ in waterlogged rice soils. J Indian Soc Soil Sci 31:135-137.

Das, K., Dang, R., Shivananda, T. N. and Sur, P. 2005. Interaction effect between phosphoprus and zinc on their availability in soil in relation to their contents in stevia (Stevia rebaudiana). Scientific World J 5:490-495.

Deo, C. and Khandelwal.2009. Effect of Zn and $\mathrm{P}$ on yield, nutrient uptake and oil content of mustard grown on the gypsum- treated sodic soil. J Indian Soc Soil Sci 57:66-70

Dev, S., Kaushik, R. D. and Gupta, V. K. 1983. Relationship between $\mathrm{P}$ and $\mathrm{Mn}$ in Chickpea. Pl Soil 72:85-90.

Dhaliwal, S. S. and Mandal, A. 2019. Transformations and Availability of Iron to wheat as Influenced by Phosphorus and Manganese
Fertilization in a Typic Haplustept Soil. Communication in soil science and plant analysis https://doi.org/10.1080/00103624.2019 .1603308 .

Dwivedi, R. S., Randhawa, N. S. and Bansal, R. L. 1975. Phosphorus- Zinc interaction I. Sites of immobilization of $\mathrm{Zn}$ in maize at a high level of phosphorus. Pl Soil 43:639-648.

Fageria, V. D. 2001. Nutrient interaction in crop plants. J Pl Nutr 24:1269-1290.

Goel, V. and Duhan, B. S. 2014. Ashwagandha (Withania somnifera L. Dunal) crop as affected by the application of farm yard manure (FYM) and inorganic phosphorus in typic torripsamment of Hisar. Afr $J$ Biotechnol 13:743-748.

Haldar, M. and Mandal, L. N. 1981. Effect of phosphorus and zinc on the growth and phosphorus, zinc, copper, iron and manganese nutrition of rice. $\mathrm{Pl}$ Soil 59:415-425.

Islam, M. N., Hoque, S. and Islam, A. 2005. Interactive effect of $\mathrm{P}$ and $\mathrm{Zn}$ in wheat, rice and mungbean. J Indian Soc Soil Sc. 53:221-227.

Javadi, M., Beuerlein, J. E. and Arscott, T. G. 1991. Effects of $\mathrm{P}$ and $\mathrm{Cu}$ on factors influencing nutrient uptake, photosynthesis and grain yield of wheat. Ohio J Sci 91:191-194.

Karelia, G. N. 1990. Response of wheat to P and $\mathrm{Zn}$ fertilization and their residual effect on bajra and jowar fodder andtheir availability in the soil. Ph.D. Thesis, Gujarat Agricultural University Sardar Krushinagar, Gujarat. 10.1099/00221287-136-2-327.

Khan, A. A. and Zande, G. K. 1976. Correlation of soil test values with the response of maize and sorghum to available $\mathrm{Zn}$ and $\mathrm{P}$. Indian Journal of Agricultural Sciences 46:259-265. 
Kuo, S. and Mikkelsen, D. S. 1981. Effect of $\mathrm{P}$ and $\mathrm{Mn}$ on growth response and uptake of $\mathrm{Fe}, \mathrm{Mn}$ and $\mathrm{P}$ by sorghum. $\mathrm{Pl}$ Soil 62:15-22.

Li, B. Y., Zhou, D.M., Cang, L., Zhang, H. L., Fan, X.H., and Qin, S. W. 2007. Soil micronutrient availability to crops as affected by long-term inorganic and organic fertilizer applications. Soil Till Res 96:166-173.

Mamo, T. and Parsons, J. W. 1987. Phosphorus micronutrient interactions in teff. Trop Agric 64:3009-3012.

Manchanda, J. S., Singh, A. and Dhaliwal, S. S. 2012. Chemical pools of $\mathrm{Zn}$ and their availability to wheat in a Typic Haplustept as influenced by $\mathrm{P}$ and $\mathrm{Mn}$ fertilization. $J$ Indian Soc Soil Sci 60:156-162.

Mandal, L. N. and Haldar, M. 1980). Influence of phosphorus and zinc application of the availability of zinc, copper, iron, manganese and phosphorus in water logged rice soils. Soil Sci 130: 251-257.

Meena, S., Lahariya, G. S., Khatik, P. and Kumar, K. 2019. Interactive Effect of Phosphorus and Zinc on Yield, Quality and Fertility Status of Soil after Harvest of Soybean. Environment and Ecology 35: 1580-1584.

Mishra, L. K. and Abidi, A. B. 2010. Effect of phosphorus and zinc fertilization on biochemical composition and bread making qualities of wheat. $J$ Progressive Agric 1:27-31

Misra, S. G. and Mishra, P. C. 1968. Effect of anions on the retention of manganese applied to soils. J Indian Soc Soil Sci 16:173-178.

Nayak, A. K. and Gupta, M. L. 2000. Influence of $\mathrm{P}, \mathrm{Zn}$ and organic matter on yield prediction in wheat. J Indian Soc Soil Sci 48:194-196.

Olsen, S. R. 1972. Micronutrient interactions. In Micronutrients in agriculture, ed. J.
J. Mortvedt, 243-264. Madison,Wisconsin, USA: Soil Science Society of America.

Patel, M. V. 1992. Studies on phosphorus zinc interaction and its effect on yield and nutrition of wheat (Var. Raj.3077) in soil. Ph.D. Thesis, Rajasthan Agricultural University, Bikaner, Rajsthan.

Prasad, R. 2012. Fertilizers and manures. Curr Sci 102:894-898.

Rao, P. V. N., Singh, A. P. and Singh, S. 1984. Effect of application of phosphorus and manganese on their availability in soil under wheatgreengram- rice sequence. J Indian Soc Soil Sci 48:130-134.

Reddy, D. D. and Yadav, B. R. 1994. Response of wheat to $\mathrm{Zn}$ and $\mathrm{P}$ in a highly calcareous soil. J Indian Soc Soil Sci 42:594-597.

Sharma, B. D., Kumar, R., Manchanda, J. S., Dhaliwal, S. S., Thind, H. S. and Singh, Y. 2011. Geospatial fertility status of Punjab soils. Bulletin published in Niche Area of excellence under Soil and water Management in high Intensity Cropping System, Department of Soil Science, PAU, Ludhiana.

Shukla, A.K., Dwivedi, B.S., Singh, V.K and Gill, M.S. 2009. Macro role of micro nutrients. Ind J Fertil 5: 11-30.

Shukla, M. and Singh, K. S. 1979. Response of wheat to zinc fertilization at different levels of phosphorus in a loamy sand soil. J Indian Soc Soil Sci 27:314-320.

Soni, M. L., Swarup, A. and Singh, M. 2000. Effect of manganese and phosphorus application on yield and nutrition of wheat in reclaimed sodic soil. Current Agric 24:105-109.

Soltangheisi, A., Rahman, Z.A., Ishak, C.F., Musa, H.M. and Zakikhani, H. 2014. Effect of phosphorus supply on the 
activity of carbonic anhydrase and the ultrastructure of chloroplast in sweet corn (Zea mays var. saccharata). Asian J Plant Sci 13: (2)51-58.

Singh, A., Manchanda, J. S., Hundal, H. S. and Bhatti, D. S. 2005.Transformation and availability o0f manganese to wheat in a typic haplustept as influenced by phosphorus and manganese fertilization. Indian J Ecol 32:226-234.

Tagliavini, M., Hogue, E. J. and Neilsen, G. S. 1991. Influence of $\mathrm{P}$ nutrition and root zone temperature on growth and mineral uptake of peech seedlings $J$ Plant Nutr 14:1267-1275

Yadav, B. S., Patel, M. S. and Hadvani, G. J. 2002. Effect of FYM, P and $\mathrm{Zn}$ on groundnut in calcareous soil. J. Indian Soc Soil Sci 39:391-393.

Zhang, Y. Q., Deng, Y., Chen, R. Y., Cui, Z. L., Chen, X. P., Yost, R., Zhang, F. S. and Zou, C. Q. 2012. The reduction in zinc concentration of wheat grain upon increased phosphorus-fertilization and its mitigation by foliar zinc application. Plant Soil 361:143-152.

\section{How to cite this article:}

Harpreet Kaur. 2019. Availability of Micronutrient Cations in Soils as Influenced by Phosphorus Fertilization- A Review. Int.J.Curr.Microbiol.App.Sci. 8(09): 1946-1952. doi: https://doi.org/10.20546/ijcmas.2019.809.224 